\title{
MOLECULAR CONTROL OF CELL FATE IN THE NEURAL CREST: The Sympathoadrenal Lineage
}

\author{
David J. Anderson \\ Howard Hughes Medical Institute, Division of Biology, \\ California Institute of Technology, Pasadena, California 91125
}

KEY WORDS: nerve growth factor, glucocorticoids, cell lineage, peripheral nervous system, neurogenesis

\section{INTRODUCTION}

A central problem in developmental neurobiology is understanding the cellular and molecular mechanisms that generate the diversity of cell types found in the nervous system. Although the general problem of cell type specification can be addressed in many non-neuronal tissues, it is particularly challenging in the nervous system, because of the enormous variety of cell types that exist, and the phenotypic plasticity they display. In recent years, several technical breakthroughs have permitted an intensive analysis of cell lineage relationships in various parts of the vertebrate nervous system. These have included the development of recombinant retroviruses for genetic marking of cell fate (Sanes et al 1986; Turner \& Cepko 1987) and membrane-impermanent lineage tracers for microinjection of single progenitor cells (Holt et al 1988; Wetts \& Fraser 1988). These techniques have revealed that in many (but not all) systems, individual neural precursor cells give rise to a variety of different cell types, thus demonstrating that they are multipotent. In the case of the neural crest, application of both techniques has indicated that many neural crest cells are multipotent, before (Bronner-Fraser \& Fraser 1988, 1989; Frank 
\& Sanes 1991) or shortly af ter (Fraser \& Bronner-Fraser 1991) they migrate from the neural tube.

If neural precursors are multipotent, how do they choose their fates? In principle, fates could be determined stochastically, be governed by cellautonomous developmental programs, or be controlled by environmental signals. In the case of the neural crest, transplantation of cell populations has indicated that the fate(s) of these populations can be altered by changing their environment (for reviews, see Le Douarin 1980, 1982). However, there have been relatively few cases in which it has been possible to identify the specific signals that control neural cell fate and study their actions on identified cells. In the optic nerve, studies of a bipotential glial progenitor cell, the $\mathrm{O} 2 \mathrm{~A}$ cell, have suggested that one fate, the oligodendrocyte, is the "default" pathway for the cell, whereas the other fate, the type 2 astrocyte, is dependent upon instructive signals (which include CNTF and extracellular matrix-associated factors) (for reviews, see Lillien \& Raff 1990; Raff 1989). Although this system has proven excellent for analysis at the cellular level, it has been less accessible for study at the molecular lcvel.

One neural crest lineage that has been investigated in detail is the sympathoadrenal (SA) lineage (Landis \& Patterson 1981). This lineage derives from neural crest cells that migrate ventrally from the apex of the neural tube to the dorsal aorta, where they aggregate and differentiate to form sympathetic neurons, or to the adrenal gland primordia, where they differentiate to form chromaffin cells (Figure 1). Chromaffin cells are round secretory cells that lack the axons and dendrites characteristic of sympathetic neurons; their secretory vesicles are also larger than those of neurons (Doupe et al 1985a). A third and minor SA cell type, the small intensely fluorescent (SIF) cell, has an intermediate morphology with short proccsses (Eranko 1975). A striking feature of these cell types is that they can be phenotypically interconverted by specific environmental signals (Patterson 1978). This plasticity has been interpreted to reflect developmental history, i.e. sympathetic neurons, adrenal chromaffin cells, and SIF cells can be interconverted because they may develop from a common embryonic progenitor cell (Anderson \& Axel 1986; Doupe et al 1985b; Unsicker et al 1989). Moreover, the ability of glucocorticoids (GC) and nerve growth factor (NGF) to interconvert or maintain these phenotypes has suggested that these factors may be important environmental determinants of cell fate in vivo (Aloe \& Levi-Montalcini 1979; Anderson 1988; Doupe et al 1985a,b; Seidl \& Unsicker 1989a,b; Unsicker et al 1978).

Recently, it has become possible to isolate SA progenitors from rat embryos by using monoclonal antibodies, and derive immortal cell lines from these progenitors (Anderson 1988; Birren \& Anderson 1990; 


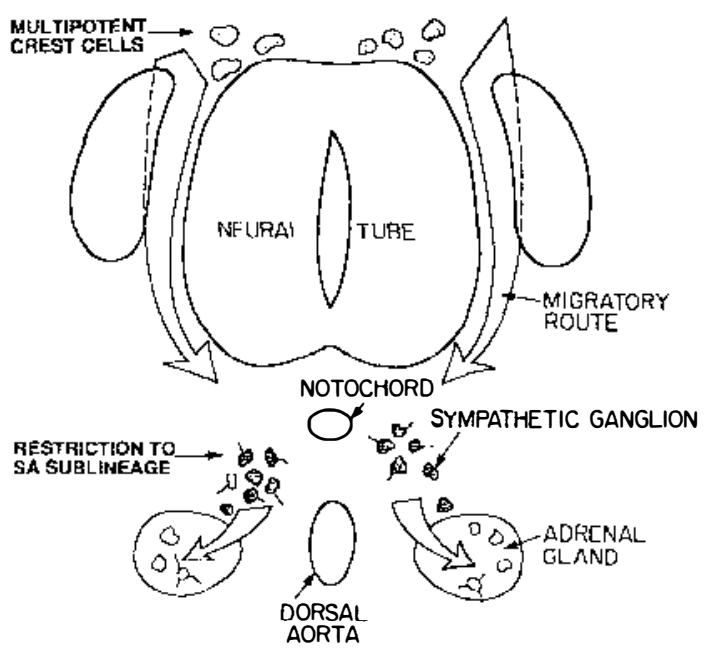

Figure 1 Schematic cross-section through a midgestational rat embryo at the caudal thoracic level, showing migratory route taken by neural crest cells that give rise to the sympathoadrenal lineage. For clarity, other crest derivatives, such as sensory neurons, melanocytes, and glia, are omitted. Cells at several different stages of development are shown in the same figure.

Carnahan \& Patterson 1991b). These advances have permitted a critical test of the "common progenitor" hypothesis and an examination of the influences of environmental signals on this embryonic cell. This review summarizes new insights into the biology of the SA lineage gained over the last several years as a consequence of these studies. A minireview on this topic has recently appeared elsewhere (Patterson 1990).

\section{HISTORICAL OVERVIEW: PLASTICITY AND DEVELOPMENTAL HISTORY}

Experimental evidence for a close developmental relationship between chromaffin cells and sympathetic neurons initially came from the observation that transplantation of postnatal adrenal medullary tissue into the anterior chamber of the eye produced outgrowth of neuritic processes (Olson 1970). Unsicker et al (1978) subsequently demonstrated that neurite outgrowth could be induced from dissociated postnatal chromaffin cells by NGF in vitro. This induction of neurite outgrowth could be blocked or delayed by GC, which suggests that the (presumably) high local concentration of steroids produced by the adrenal cortex (Roos 1967) is important for maintaining the endocrine phenotype of the medullary cells. 
Nerve growth factor also promoted neurite outgrowth from a clonal cell line, PC12, derived from a rat adrenalmedullary tumor (Greene \& Tischler 1976). Moreover, injections of NGF into rat fetuses caused the replacement of chromaffin cells by ganglionic neurons in situ (Aloe \& Levi-Montalcini 1979). Taken together, these data revealed that the chromaffin phenotype is plastic and identified NGF and GC as environmental signals of potential importance in controlling the fate of these cells in vivo.

Although these early in vitro studies documented short-term neurite outgrowth from chromaffin cells in response to NGF, they did not determine whether these endocrine cells could undergo a complete phenotypic conversion into bona fide sympathetic neurons. This was resolved by Doupe et al (1985a), who demonstrated that individual chromaffin cells could convert into cells that are morphologically and antigenically indistinguishable from true sympathetic neurons, when exposed to NGF for several weeks. Furthermore, such a transdifferentiation occurred in single cells, in the absence of DNA synthesis or cell division (Doupe et al 1985b) [however, in the absence of mitotic inhibitors, NGF exerted a mitogenic effect on chromaffin cells (Lillien \& Claude 1985)]. The conversion to a neuronal phenotype also involved the de novo induction of expression of neuron-specific genes (Anderson \& Axel 1985). In these studies, GC not only inhibited neuronal transdifferentiation, but also acted as a survival factor for the chromaffin cells (Doupe et al 1985a).

Based on these and the preceding observations, it was hypothesized that chromaffin cells and sympathetic neurons derive from a common embryonic progenitor (Doupe et al 1985b; Landis \& Patterson 1981). A cell with the properties expected of such a progenitor was identified in cultures of neonatal sympathetic ganglia (Doupe et al 1985b) (although the lack of markers for this cell made it difficult to establish its relationship to embryonic precursor cells in vivo). This cell could differentiate into a SIF-like phenotype in moderate concentrations of GC $\left(10^{-8} \mathrm{M}\right)$ or to an adrenergic chromaffin cell in micromolar GC. Once generated, such SIFlike cells could be converted to sympathetic neurons by exposure to NGF (Doupe et al 1985b). This observation, coupled with the fact that the conversion of chromaffin cells to sympathetic neurons appeared to occur through a SIF-like intermediate, led to the proposal that SIF cells represent the cmbryonic progenitor of both adrenal medullary cells and sympathetic neurons (Doupe et al 1985b). High GC would favor the differentiation of SIF cells into chromaffin cells. Nerve growth factor would promote their differentiation into sympathetic neurons. And, a combination of NGF and moderate concentrations of GC would maintain or stabilize the SIF phenotype. This idea was appealing in that it provided a role for SIF cells (Eranko 1975), whose function had previously been controversial. 


\section{Fetal SA Progenitors are Bipotential, but Distinct from SIF Cells}

A direct test of the bipotential progenitor hypothesis was made possible by the development of immunologic methods to isolate fetal SA progenitors. These cells have been isolated from E14.5 rat adrenal glands (Anderson 1988; Anderson \& Axel 1986) by using monoclonal antibody HNK-1 (Abo \& Balch 1981), and from sympathetic ganglia (Carnahan \& Patterson 1991b) by using novel monoclonal antibodies generated by an immunosuppression technique (Carnahan \& Patterson 1991a). Progenitors from fetal adrenal glands have also been isolated by density gradient centrifugation (Seidl \& Unsicker 1989a). Quantitative analysis of such purified cell populations (Anderson \& Axel 1986; Carnahan \& Patterson 1991b), as well as serial observations of identified cells (Anderson \& Axel 1986; Michelsohn \& Anderson 1992) has confirmed that many such progenitors are bipotential, able to develop into either chromaffin cells or sympathetic neurons depending upon the culture conditions. Nevertheless, the SA progenitor appears to have lost the ability to give rise to other crest derivatives, such as glia (D. L. Stemple and D. J. Anderson 1991, unpublished), and therefore represents a relatively late stage in neural crest lineage diversification. The idea that the glia and sympathoadrenal lineages diverge early in sympathetic gangliogenesis is supported by retroviral lineage-tracing experiments in fetal superior cervical ganglion (SCG) (Hall \& Landis 1991a).

Fetal SA progenitors can be demonstrated to be bipotential in vitro, but do such cells exist in vivo? Individual cells coexpressing neuron-specific and chromaffin-specific antigenic markers have been observed in early (E12.5) sympathetic ganglia primordia (Anderson et al 1991; Carnahan \& Patterson, 1991a). Subsequently, the chromaflin-specific markers are lost by the cells that remain in the ganglia (Anderson et al 1991; Carnahan \& Patterson 1991a), whereas the neuron-specific markers are lost by progenitors that continue migrating to the adrenal gland (Anderson 1988; Anderson \& Axel 1986; Vogel \& Weston 1990). The observation of such transiently dual phenotype cells provides circumstantial evidence for the existence of a bipotential SA progenitor in vivo. Is this cell a SIF cell? Although the morphology and high catecholamine content of the embryonic SA progenitor is similar to that of a postnatal SIF cell, SA progenitors and SIF cells are distinct by antigenic criteria (Carnahan \& Patterson 1991a), and SIF cells develop later, not earlier, than principal neurons in sympathetic ganglia (Hall \& Landis 1991b). These data suggest that the embryonic SA progenitor is different from a SIF cell. However, SIF cells have a similar developmental potential as the SA progenitor (Doupe et al 
$1985 \mathrm{~b}$ ) and might represent a postnatal/adult form of the SA progenitor (Carnahan \& Patterson 1991b), as has been described in the glial 02A lineage (Wolswijk \& Noble 1989).

\section{ROLE OF POLYPEPTIDE GROWTH FACTORS IN THE NEURONAL DIFFERENTIATION OF SA PROGENITOR CELLS}

\section{Fetal SA Progenitors are Initially Responsive to Fibroblast Growth Factor (FGF) but not to NGF}

The ability of NGF to trigger neurite outgrowth from postnatal chromaffin cells, SIF cells, and $\mathrm{PCl} 2$ cells initially suggested that NGF is an important determinant of neuronal fate in the SA lineage. Indeed, neonatal postmitotic sympathetic neurons are absolutely dependent upon NGF for survival both in vitro (Chun \& Patterson 1977; Levi-Montalcini \& Angeletti 1963) and in vivo (Levi-Montalcini \& Booker 1960). But, freshly isolated SA progenitors from fetal adrenal glands are initially unresponsive to NGF, by criteria of neurite outgrowth, mitotic rate, and survival (Anderson \& Axel 1986; S. J. Birren and D. J. Anderson 1991, unpublished). Similar observations have been made for neuronal precursors from chick (Ernsberger et al 1989a) and mouse (Coughlin \& Collins 1985) sympathetic ganglia. These data raise several new questions: Why are SA progenitors unresponsive to NGF? Which factors promote the acquisition of NGF-responsiveness and NGF-dependence? Are there other factors that substitute for NGF in the early stages of neuronal differentiation?

Answers to some of these questions have come, in part, from studies of an SA progenitor cell line, called MAH (Myc-infected, Adrenal-derived, $\mathrm{HNK}-1^{+}$) cells. MAH cells were produced by retroviral transduction of the avian $v-m y c$ oncogene into SA progenitors isolated from fetal adrenal glands by fluorescence-activated cell sorting; their morphology and antigenic phenotype are similar to those of their primary counterparts (Birren \& Anderson 1990). Like primary SA progenitors, MAH cells fail to respond to NGF by criteria of neurite outgrowth, survival, or induction of neuron-specific genes (Birren \& Anderson 1990). The large number of homogeneous cells provided by the MAH line has permitted a molecular analysis of NGF receptor expression in SA progenitors. Northern blot analysis has indicated that MAH cells grown in the absence of dexamethasone express neither mRNA encoding p75 (Birren \& Anderson 1990), the low affinity NGF receptor (Johnson et al 1986; Radeke et al 1987), nor p140 ${ }^{\text {trk }}$ (Birren et al 1992), recently identified as a signal-trans- 
ducing component of the NGF receptor (Kaplan et al 1991a; Klein et al 1991). Thus, the lack of NGF responsiveness appears due, at least in part, to a lack of NGF receptor expression. However, it may also reflect the absence of some other component(s) of the NGF signal-transduction pathway.

If NGF does not promote the initial neuronal differentiation of SA progenitors, do other factors play this role? Experiments in $\mathrm{PCl} 2$ cells have identified bFGF (Rydel \& Greene 1987; Togari et al 1985), interleukin-6 (Satoh et al 1988), and "pleiotrophin" (Kuo et al 1990; Li et al 1990) as factors able to mimic the ability of NGF to induce neurite outgrowth and, in the case of bFGF, neuron-specific gene expression (Leonard et al 1987; Stein et al 1988). In postnatal adrenal chromaffin cells, both bFGF (Stemple et al 1988) and aFGF (Claude et al 1988) promote neuronal differentiation and increase cell prolif eration. Unlike NGF, however, FGF cannot act as a long-term survival factor for sympathetic neurons (Stemple et al 1988). Similarly, bFGF can induce proliferation and neurite outgrowth from both MAH cells (Birren \& Anderson 1990) and primary SA progenitor cells (S. J. Birren and D. J. Anderson 1991, unpublished), but does not support their long-term survival. Taken together, these results suggest that FGF, rather than NGF, may promote the proliferation and initial neuronal differentiation of embryonic SA progenitors, whereas NGF acts as a survival factor for mature neurons. In chromaffin cells, FGF can induce neuronal differentiation independent of its ability to induce proliferation (Stemple et al 1988); it is not yet clear whether this is also true for embryonic SA progenitors.

Other factors besides bFGF also stimulate the proliferation or survival of immature sympathetic neuroblasts, including depolarization, insulin, insulin-like growth factor I (IGF-I), and vasoactive intestinal peptide (DiCicco-Bloom \& Black 1988, 1989; DiCicco-Bloom et al 1990; Pincus et al 1990; Wolinsky et al 1985); for review see Rohrer (1990). In such studies, it is often difficult to distinguish between the mitogenic effect of a growth factor and its ability to enhance simply the survival of proliferating cells without affecting their rate of cell division. Two other "growth" factors, ciliary neurono-trophic factor (CNTF) and cholinergic differentiation factor/leukemia inhibitory factor (CDF/LIF), inhibit the proliferation of sympathetic neuroblasts and MAH cells (Ernsberger et al 1989; Ip et al 1992). With the exception of NGF (Levi-Montalcini \& Booker 1960; Rohrer et al 1988), the requirement for any of these growth factors in sympathetic neuronal proliferation or differentiation in vivo has not yet been assessed. However, embryonic chick sympathetic ganglia contain bFGF immunorcactivity at early stages of gangliogenesis (Kalcheim \& Neufeld 1990). 
Induction of NGF Receptors and NGF-Responsiveness in $S A$ Progenitors

The survival of sympathetic and other neurons is independent of NGF before their axons reach the sources of NGF in the periphery (Davies et al 1987; Korsching \& Thoenen 1988). How do differentiating sympathetic neurons acquire their responsiveness to, and ultimately thcir trophic dependence upon, NGF? Because SA progenitors initially do not appear to express NGF receptors, a critical early step must be the induction of such receptors. In MAH cells, treatment with both FGF and NGF (but not with either factor alone) leads to a small population of cells $(0.5-10 \%)$, which differentiate to postmitotic neurons. Such cells are NGF-dependent, which implies that they express functional NGF receptors (Birren \& Anderson 1990). This suggested that FGF might induce the expression of NGF receptors, and a low-level induction of p75 (LNGFR) mRNA was observed in MAH cells cxposed to FGF for several days (Birren \& Anderson 1990).

Experiments with cloned NGF receptor genes suggest that the expression of p75 is probably not sufficient for NGF responsiveness [and may not be necessary, either (Weskamp \& Reichardt 1991)], and that p140 $10^{t r k}$ is required to form functional, high-affinity NGF receptors (Hempstead et al 1991). In MAH cells, p $140^{t r k}$ mRNA is not directly induced by FGF (or any other growth or neurotrophic factors tested); however, it is induced by membrane depolarization, which also induces a functional NGF-response (Birren et al 1992). Depolarization does not induce neurite outgrowth, however, which indicates that the induction of trk can be experimentally uncoupled from neuronal differentiation. The ability of FGF to induce NGF-responsiveness in a small proportion of MAH cells (Birren \& Anderson 1990) may reflect an indirect induction of trk expression, perhaps via synaptic activity. In primary chick sympathetic neuroblasts, depolarization augmented cell survival in the presence of NGF (Ernsberger et al 1989a), although the mechanism of this effect was not investigated. Taken together, however, these results suggest that the electrical excitation of developing sympathetic neuroblasts may stimulate their acquisition of trophic-factor responsiveness. Such a mechanism could coordinate the formation of stable presynaptic and postsynaptic connections by a developing neuron.

Other mechanisms may also contribute to the acquisition of trophic factor responsiveness and dependence in developing neuroblasts. In chromaffin cells, FGF can induce an NGF-dependence in transdifferentiating neurons that are already NGF-responsive (Stemple ct al 1988). Seemingly spontaneous acquisition of trophic factor dependence has been observed for primary sensory neurons in vitro (Vogel \& Davies 1991); howcver, it 
was not determined whether these cells were already responsive to the neurotrophic factor [brain-derived neurotrophic factor (BDNF)] at the time of their initial isolation. Retionic acid induces both NGF-dependence and the expression of high-affinity NGF receptors in chick sympathetic neuroblasts that bear low affinity NGF receptors (Rodriguez-Tébar \& Rohrer 1991). In the rat SA progenitor, however, retinoic acid does not appear to induce NGF responsiveness or expression of $\mathrm{pl} 40^{\text {trk }} \mathrm{mRNA}$ (Birren et al 1992); this difference may reflect either a species difference or differences in the relative stages of development examined in the two systems. The availability of cloned probes for both $\mathrm{p} 75$ and $\mathrm{p} 140^{\text {trk }}$ should help resolve these issues.

\section{ROLE OF GC IN CHROMAFFIN CELL DIFFERENTIATION}

\section{Positive and Negative Action of GC on the SA Progenitor}

The migration of SA progenitors to the adrenal gland primordium brings them to a microenvironment that contains a high concentration of GC hormones, synthesized by the adrenal cortex. Earlier studies have established two distinct influences of GC on the chromaffin phenotype, one positive and one negative. Glucocorticoids act positively to upregulate the expression of phenylethanolamine- $\mathrm{N}$-methyl transferase (PNMT), the epinephrine-synthesizing enzyme (Bohn et al 1981; Jiang et al 1989; Pohorecky \& Wurtman 1971; Teitelman et al 1982; Wurtman \& Axelrod 1966). This gene is expressed by a majority of adrenal chromaffin cells, but not by sympathetic neurons (Bohn et al 1982). Glucocorticoids also act negatively to inhibit neuronal differentiation induced by both NGF (Unsicker et al 1978) and FGF (Stemple et al 1988).

The ability of GC to exert both positive and negative effects on the SA progenitor reflects the capacity of the GC receptor (GCR) to function as both a positive- and negative-acting transcriptional regulatory molecule (for review, see Beato 1989). In the case of the SA progenitor, some of the targets of these positive and negative actions of the GCR are known. The sequence of the PNMT gene contains several consensus glucocorticoidresponse elements (GREs) (Batter et al 1988), and at least one of these is functional in cell transfection assays (Ross et al 1990). These data suggest that the PNMT gene is a direct target of positive regulation by GC. Glucocorticoids also repress the expression of several neuron-specific genes, including pcripherin (Lconard et al 1987), SCG10 (Stein et al 1988), and GA P-43 (Federoff et al 1988), in PC1 2 cells. Negative GREs have not yet been identified for these genes in functional assays; therefore, it is not clear whether the action of GC on these genes is direct. However, a 
promoter fragment from the metalloprotease gene transin (stromelysin) contains elements for both positive regulation by NGF, and ncgative regulation by GC, in transfected $\mathrm{PCl} 2$ cells (Machida et al 1989). Further analysis of this promoter should shed light on the inhibitory actions of GC.

Glucocorticoids exert both positive and negative influences on embryonic SA progenitors, as well as on $\mathrm{PCl} 2$ cells, but these influences occur on different developmental schedules. Primary E14.5 SA progenitors are competent to respond to GC by inhibition of neuronal differentiation within the first 15-24 hours of culture, but do not express PNMT (Michelsohn \& Anderson 1992). Although GCs are absolutely required for PNMT expression (Seidl \& Unsicker 1989b), competence to express PNMT does not develop until after several days in culture (Michelsohn \& Anderson 1992), which reflects the schedule of PNMT appearance in vivo (Bohn et al 1981; Ehrlich et al 1989; Teitelman et al 1982). In vivo,PNMT expression is also preceded by the inhibition of neuronal differentiation, as indicated by the extinction of neuron-specific markers (Anderson \& Axel 1986; Anderson et al 1991; Anderson \& Michelsohn 1989; Vogel \& Weston 1990).

Both the early and late effects of GC appear mediated by the type II GCR (Anderson \& Michelsohn 1989; Michelsohn \& Anderson 1992). How can the same receptor control two different developmental events in the same cell at two different times? One clue comes from a pharmacological analysis of GC actions. A fivefold higher dose of GC is required for halfmaximal induction of PNMT, than for half-maximal inhibition of neurite outgrowth. This suggests that the induction of PNMT transcription may require a higher concentration of ligand-bound GCR than does the repression of neuron-specific genes. The idea that different GC-responsive genes within the same cell may require different levels of ligand-bound receptor is supported by recent studies of model promoters (Diamond et al 1990; Simons et al 1989). The timing of PNMT induction might then be determined by the accumulation of GCR to a threshold level (Anderson $\&$ Michelsohn 1989). Consistent with this idea, GCR levels in fetal chromaffin cells increase in parallel with PNMT expression (Seidl \& Unsicker 1989b), and $\mathrm{PNMT}^{+}$chromaffin cells appear to have higher levels of GCR immunoreactivity than $\mathrm{PNMT}^{-}$chromaffin cells (Ceccatelli et al 1989).

SEQUENTIAL STEPS IN CHROMAFFIN DIFFERENTIATION ARE DEPENDENT EVENTS Why should chromaffin cell development involve two sequential GCdependent steps? If SA progenitors are cultured for two days in the absence of GC, many cells extend neurites; these cells subsequently fail to express PNMT in response to GC, as if committed to neuronal differentiation 
(Michelsohn \& Anderson 1992). If neuronal differentiation is suppressed by progesterone during this initial period, then an increased number of precursors acquire competence to express PNMT (Michelsohn \& Anderson 1992). Thus, the first step in chromaffin differentiation (the inhibition of neuronal commitment) is a prerequisite for the second step (the decision to express PNMT). Neuronal commitment correlates with the expression of an antigenic marker, B2 in vivo (Anderson \& Axel 1986; Anderson et al 1991)(Figure 2). Consistent with the in vitro data, a lack of B2 expression by adrenal medullary cells precedes their expression of PNMT in vivo (Anderson et al 1991). Such a two-step mechanism may ensure that epinephrine is synthesized only by those progenitors that have first migrated

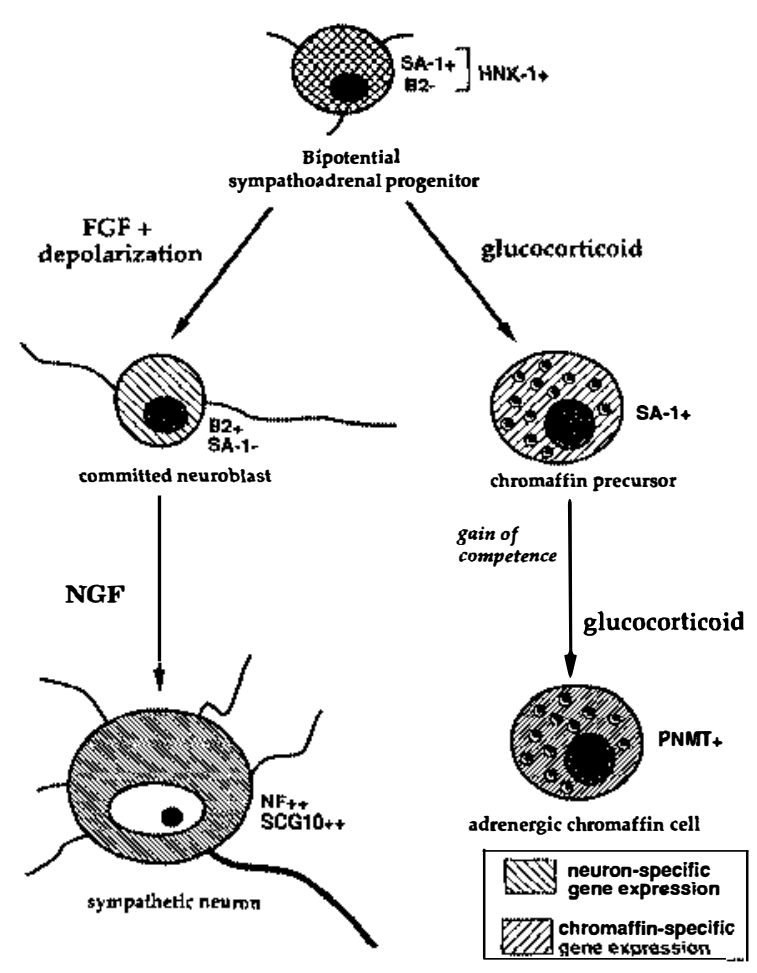

Figure 2 Progressive stages in the development of the SA lineage. Changes in marker expression that correlate with these stages are shown. Cross-hatched lines in bipotential SA progenitor indicate that both neuron-specific and chromaffin-specific genes are coexpressed. Committed neuroblasts have lost competence to respond to GC by expression of a chromaffin phenotype. Acquisition of NGF receptors appears to occur at or after the committed neuroblast stage, but also occurs in chromaffin precursors. For further details, see Figure 6 in Carnahan \& Patterson (1991b). 
to the adrenal gland. Not all chromaffin cells express PNMT, however (Hillarp \& Hökfelt 1953). This may reflect the fact that GC do not induce competence per se, but only increase the probability that competence will be acquired (Michelsohn \& Anderson 1992).

Taken together, these recent studies indicate that the development of both chromaffin cells and sympathetic neurons is progressive and can be dissected into a series of steps (Figure 2). In vitro, these steps appear to involve changes in the responsiveness of cells to environmental signals: Developing sympathetic neurons gain responsiveness to NGF and lose sensitivity to GC-inhibition, whereas developing chromaffin cells acquire competence to express PNMT. These steps are associated with changes in antigenic phenotype (Figure 2), thus allowing them to be identified in vivo (Anderson et al 1991; Carnahan \& Patterson 1991a). An analogous series of stepwise changes in factor responsiveness, which are correlated with changesin cell morphology and antigenic phenotype, has been documented for glial progenitors in the 02A lineage (Gard \& Pfeiffer 1990). Such progressive mechanisms seem likely to be a general feature of vertebrate neurogenesis and have been identified genetically in invertebrate nervous systems, as well (for reviews, see Ghysen \& Dambly-Chaudiere 1989; Jan \& Jan 1990).

\section{Regulatory Circuits Controlling the Chromaffin-Neuron Decision}

Glucocorticoids inhibit the neuronal differentiation of the SA progenitor in two ways: They directly suppress expression of the neuronal phenotype and they block the ability of FGF and NGF to promote this phenotype. In PC 12 cells, GCs inhibit the ability of FGF and NGF to up-regulate ncuron-specific genes (Leonard et al 1987; Stein et al 1988b). Intcrestingly, this antagonism is a "two-way street": FGF and NGF can inhibit the ability of GC to upregulate chromaffin-abundant genes, such as TH (Stein et al 1988). In other words, at saturating concentrations, FGF/NGF and GC reciprocally inhibit each other's actions. What is the molecular basis of such reciprocal inhibition?

Recently, novel mechanisms of transcriptional regulation by steroid hormone receptors have been uncovered (for review, see Schüle \& Evans 1991). These mechanisms may have relevance for understanding the reciprocal antagonism between $\mathrm{FGF} / \mathrm{NGF}$ and $\mathrm{GC}$ in the SA lineage. Glucocorticoid receptors interact with members of the AP-1 family of transcriptional regulatory proteins, such as c-fos and c-jun. In some cases, this interaction occurs "off" the DNA (Schüle et al 1990; Yang-Yen et al 1990); in others it occurs "on" the DNA (Diamond et al 1990). In PCl2 cells, both FGF and NGF cause an induction of such AP-1 genes as c-jun 
(for review, see Sheng \& Greenberg 1990). Although it is not yet certain that AP-1 molecules are required for neuronal differentiation in the SA lineage, overexpression of c-jun promotes autonomous neuronal differentiation of PC12 cells (I. Verma 1991, personal communication). The ability of GCR to inhibit the activity of AP-1 could, therefore, provide a molecular mechanism for the antagonism of FGF/NGF-induced neuronal differentiation by corticosteroids. Moreover, because an "off-the-DNA" interaction between AP-1 and the GCR results in a mutual inhibition of DNA-binding activity (Schüle et al 1990; Yang-Yen et al 1990), it could explain the reciprocal antagonism observed between FGF/NGF and GC at saturating ligand concentrations (Figure 3).

Such a mechanism is particularly attractive, because it would generate a "titratable" system: Progenitors containing more ligand-bound GCR than AP-1 would favor chromaffin differentiation, whereas progenitors containing more active AP-1 than GCR would favor neuronal differentiation. These two situations would obtain when the dominant environmental signals were GC or FGF/NGF, respectively. In this way, such a regulatory circuit (Figure 3 ) would create a cell whose choice of fate was exquisitely sensitive to the relative concentrations of competing signals in its local environment - precisely the behavior observed for SA progenitor cells. The actual role of GCR-AP-1 antagonistic interactions in the SA progenitor remains to be investigated. However, the establishment of thesc mechanisms in model systems provides a promising new handle on the regulatory circuits that control the chromaffin-neuron decision.

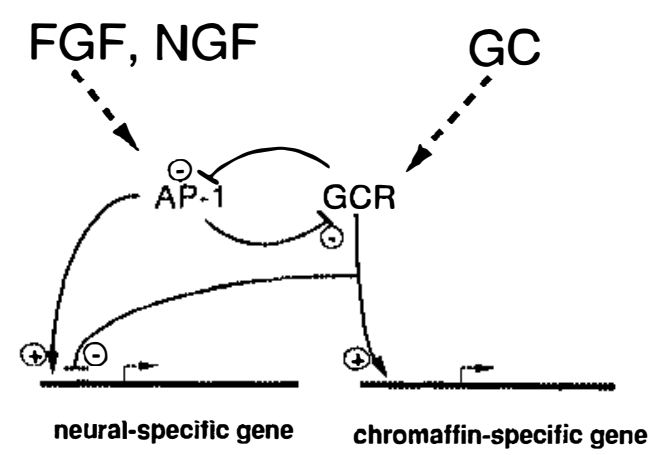

Figure 3 Hypothetical regulatory interactions between transcription factors in the AP-1 family and the GC receptor. These interactions occur in model systems, but have not yet been documented in the SA lineage. Positive and/or negative effects of AP-1 and GCR on the transcription of neuron-specific and chromaffin-specific genes are also illustrated. There is no evidence for a direct negative effect of AP-1 on chromaffin-specific gene expression, although this has not been excluded. 


\section{THE SA PROGENITOR HAS THE POTENTIAL TO GENERATE NON-CATECHOLAMINERGIC DERIVATIVES}

\section{Coexpression of Multiple Neurotransmitter Enzyme Genes in $S A$ Progenitors}

The repertoire of fates available to the SA progenitor is not restricted to catecholaminergic cell types. Sympathetic neurons and chromaffin cells can convert from a catecholaminergic to a cholinergic neurotransmitter phenotype in vitro (Doupe et al 1985b; Ogawa et al 1984; Patterson \& Chun 1977). Experiments in vivo have shown that such a conversion actually occurs for the sympathetic neurons that innervate the sweat glands (Landis \& Keefe 1983; Schotzinger \& Landis 1988, 1990). Biochemical experiments in vitro have identified CDF/LIF (Yamamori et al 1989) and CNTF (Saadat et al 1989) as two molecules that are sufficient to induce the noradrenergic to cholinergic conversion. Whether these molecules are actually the cholinergic differentiation factors in the sweat gland is now under investigation (Rao \& Landis 1990). The demonstration of cholinergic potential in sympathetic neurons and adrenal chromaffin cells raises questions regarding how early in the SA lineage this potential is established, and whether SA progenitors have other developmental potentials, as well.

Recent experiments have shed light on the answers to both of these questions. ACh synthesis has been detected in both primary SA progenitors and in MAH cells (Vandenbergh et al 1991). In addition, MAH cells transcribe low levels of ChAT mRNA. These data suggest that the cholinergic potential is established early in the SA lineage, before the choice between chromaffin and neuronal fates. In addition to ChAT mRNA, MAH cells contain low levels (approximately one copy per cell) of tryptophan hydroxylase (TpH) mRNA (Vandenbergh et al 1991). TpH transcripts were also detected in tissue from superior cervical ganglia and adrenal medulla, which indicates that the expression detected in $\mathrm{MAH}$ cells is not an artifact of immortalization. By contrast, no transcripts from either of the two glutamic acid decarboxylase (GAD) genes, GAD1 and GAD2, were detected in SA lineage cells or tissues (Vandenbergh et al 1991). These data suggest that SA progenitors may express a restricted repertoire of neurotransmitter biosynthetic enzyme genes.

The detection of $\mathrm{TpH}$ transcripts in $\mathrm{MAH}$ cells suggests that SA progenitors may have a serotonergic potential, as well as a cholinergic and catecholaminergic potential. Consistent with this notion, neonatal sympathetic neurons can synthesize serotonin in response to heart cell conditioned medium (Sah \& Matsumoto 1987). Is this serotonergic potential 
actually utilized in vivo? Serotonin is one of the neurotransmitters thought to be used by enteric neurons and their endocrine counterparts, thyroid medullary " $C$ " cells, both of which derive from the neural crest (Barasch et al 1987). This is consistent with the possibility that the SA progenitor may also give rise to enteric neurons (Figure 4), as discussed below.

\section{SA Progenitors and Enteric Progenitors Are Similar}

Circumstantial evidence supports the hypothesis that progenitors of enteric neurons may be similar, if not identical, to SA progenitors. A population of cells in the embryonic foregut transiently expresses SA lineage markers, including TH (Cochard et al 1978; Teitelman et al 1978), DBH, and highaffinity catecholamine uptake (Baetge \& Gershon 1989; Jonakait et al 1985). Expression of these markers in the gut appears at E11.5-E12.5, the same time as in sympathetic ganglia. The gut cells also express SA-1 (Carnahan et al 1991) and, subsequently, B2, like neuroblasts in the sym-

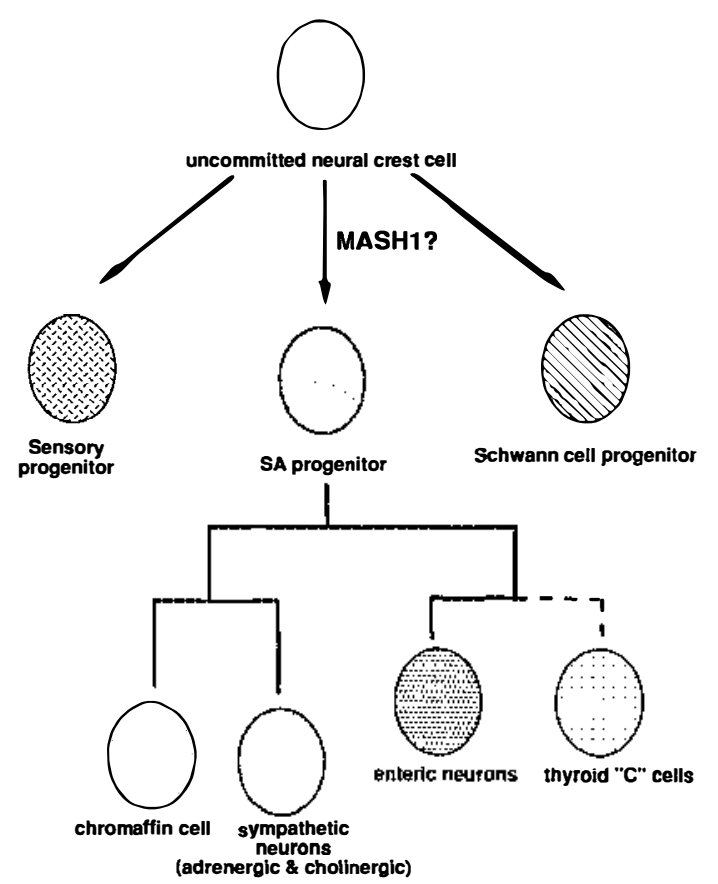

Figure 4 The SA lineage in the context of other neural crest lineages. A progenitorprogeny relationship between SA precursors and enteric neurons has not yet been formally demonstrated. Dotted line indicates that the lineage relationship between SA progenitors and thyroid $\mathrm{C}$ cells is speculative. MASHI is hypothesized to play a role in the restriction of multipotent neural crest cells to the SA lineage, but the nature of this role is not established. 
pathetic ganglia (Anderson et al 1991; Carnahan et al 1991). Not only are SA lineage markcrs expressed in gut cells, but conversely serotonin (Soinila et al 1989), a marker of enteric neurons, is transiently expressed by SA progenitors. Although shared expression of antigenic markers cannot rigorously prove a lineage relationship, the fact that so many independent gene products are expressed by both cells in the sympathetic ganglia and cells in the foregut suggests that these two populations may be closely related (Carnahan \& Patterson 1991a).

The SA progenitor-like cells in the embryonic foregut are likely to bc precursors of enteric neurons. This conclusion is based on the fact that neuronal "linking markers," such as neurofilament and DBH, are initially coexpressed with SA lineage markers in the foregut population and persist in enteric neurons after the SA markers have disappeared (Baetge \& Gersohn 1989; Baetge et al 1990; Carnahan et al 1991). The persistent expression of such linking markers suggests that the transient SA progenitor cell-like population in the gut does not die, but rather extinguishes expression of such genes as $\mathrm{TH}$ and SA-I and differentiates into enteric neurons. This implies that the environment of the gut may influence a decision between a sympathoadrenal and an enteric phenotype. Consistent with this idea, injections of NGF in vivo prolong $\mathrm{TH}$ expression in gut neurons (Kessler et al 1979).

The idea that the environment of the gut suppresses the expression of SA properties is also supported by in vitro experiments. Precursors of enteric neurons from the vagal neural crest express TH if cultured in NGF (Mackey et al 1988) and extinguish TH when cocultured with gut tissue (Coulter et al 1988). It is not yet known whether coculture with gut tissue can suppress TH expression in sympathetic neuroblasts. Direct tests of the postulated lineage relationships between SA progenitors and enteric neurons are clearly required before further progress on this problem can be made. But the available data, while indirect and circumstantial, suggest that the SA progenitor may have a repertoire of several developmental fates (Figure 4) (Carnahan et al 1991). This repertoire appears to be reflected in the transcriptional activation of a battery of genes that subserve several possible classical neurotransmitter phenotypes, including catecholaminergic, cholinergic, and serotonergic (Vandenbergh et al 1991), as well as multiple neuropeptide phenotypes (Nawa \& Patterson 1990). The expression of a particular phenotype from this repertoire is then selected according to the various inductive and repressive signals encountered by the cell as it migrates to different embryonic environments (Anderson \& Axel 1986). Following their differentiation into postmitotic cells, sympathetic neurons can undergo further phenotypic diversification with respect to their neurotransmitter and neuropeptide 
content, in response to target-derived instructive signals (for review, see Patterson 1990).

\section{COMMITMENT OF EARLY NEURAL CREST CELLS TO THE SA LINEAGE}

If SA progenitors have a restricted repertoire of developmental fates, how does this repertoire become established in neural crest ontogeny? Single cell lineage tracing experiments in vivo (Bronner-Fraser \& Fraser 1989; Frank \& Sanes 1991; Fraser \& Bonner-Fraser 1991), as well as clonal analyses in vitro (Baroffio et al 1988; Dupin et al 1990; Sieber-Blum \& Cohen 1980) have established that many early neural crest cells are multipotent. An individual cell may give rise to a clone containing not only catecholaminergic (SA) derivatives, but also glia, melanocytes, and sensory neurons. Because the SA progenitor seems to have lost the capacity to generate these latter three cell types, it may have become developmentally restricted. How might such a restriction event occur?

Experiments in vitro using avian neural crest cells have suggested that environmental influences, such as soluble factors (Howard \& BronnerFraser 1985), extracellular matrix (Maxwell \& Forbes 1990a,b), and the timing of cell dispersal (Vogel \& Weston 1988) may influence the expression of the catecholaminergic phenotype. Ablation and rotation experiments in chick embryos have indicated that the notochord/floorplate and the dorsal aorta are required for the expression of catecholamines by neural crest cells in vivo (Stern et al 1991). The observation that SA progenitors can develop in different types of clones, which contain various subsets of other crest derivatives, has suggested that commitment may occur by a stepwise process involving "oligopotential" (i.e. partially restricted) intermediates (Anderson 1989; LeDouarin et al 1991; Sieber-Blum 1990). However, there is currently little evidence to distinguish such a progressive model from a stochastic one, a problem that has dogged the dissection of lineage commitment in the immune system for many years (Suda et al 1984). The study of lineage restriction in the neural crest has been limited by the difficulty of obtaining early markers whose expression precedes that of such differentiation products as TH (Barald 1988). Such early markers can be useful in identifying influences that might predispose cells to a particular sublineage.

\section{A Vertebrate Homologue of Drosophila achaete-scute Is an Early Marker of SA Lineage Commitment}

One recent approach that has proven productive in identifying such an early marker is to isolate vertebrate homologues of Drosophila genes that control early stages in neurogenic determination. The achaete-scute complex 
of Drosophila contains four genes whose function is required for the development of subsets of neuroblasts in appropriate positions in the fly embryo (Ghysen \& Dambly-Chaudiere 1988). Molecular analysis of this complex has revealed that these genes encode nuclear regulatory proteins of the basic helix-loop-helix (bHLH) class (Alonso \& Cabrera 1988; Gonzalez et al 1989; Romani et al 1989; Villares \& Cabrera 1987). Included in this general class are $\mathrm{MyoD}$ and related proteins, encoded by mammalian genes that play a central role in myogenic determination (for review, see Weintraub et al 1991). The isolation of a Drosophila MyoD homologue, nautilus, which is specifically expressed in fly myogenic precursors (Michelson et al 1990), suggested that there has been a remarkable parallel conservation of amino acid sequenceand tissue-specificity for at least some bHLH cell-type determination genes. Consistent with this idea, a recently isolated Mammalian AchaeteScute-Homologous (MASH)gene, MASHI (Johnson et al 1990), is specifically expressed by subsets of neural precursors in the rat embryo (Lo et al 1991).

A striking feature of MASHl expression in the peripheral nervous system is that it is restricted to sympathetic ganglion primordia, but appears one day earlier than differentiation genes, such as TH (Lo et al 1991). MASH 1 expression subsequently overlaps that of $\mathrm{TH}$, but is eventually extinguished. MASHI is also expressed by scattered cells in the foregut, which further supports the idea of a close developmental relationship between SA and enteric crest derivatives (see above). MASH1 is notably absent from dorsal root ganglia, glia, and melanocytes, as well as from migrating neural crest cells. It thus appears to mark neural crest cells immediately before their restriction to the SA lineage. In the CNS, MASH1 is expressed by positionally restricted subsets of precursor cells in the spinal cord and forebrain (Lo et al 1991). The fact that MASH1 is a transcription factor (Johnson et al 1992) and is homologous to a family of neural determination genes in Drosophila further suggests that it may have a causal role in SA lineage commitment (Figure 4). The isolation of vertebrate homologues of other Drosophila genes involved in neural determination (for review, see Campos-Ortega \& Jan 1991), such as daughterless (Murre et al 1989a,b), Notch (Coffman et al 1990; Weinmaster et al 1991), and the RNA-binding protein Elav (Marusich \& Weston 1992; Szabo et al 1991), suggests that this general approach should be successful in identifying molecules that will, at the very least, serve as useful markers and may at best provide handles on molecular mechanism.

\section{Transcription Factors for Genes Expressed in $S A$ Progenitors}

Another approach to the molecular biology of SA lincage commitment is to isolate nuclear regulatory factors required for the expression of genes, 
such as SCG10, neurofilament, TH, and DBH, which are specifically transcribed in SA progenitors. A first step toward this goal is to delineate the cis-acting elements with which these factors interact. A $5.8 \mathrm{~kb}$ fragment of the human dopamine- $\beta$ hydroxydase (DBH) gene has recently been shown to direct the expression of $\beta$-galactosidase to developing sympathetic ganglia and adrenal medulla in transgenic mice (Kapur et al 1991; Mercer et al 1991). Surprisingly, however, expression is also detected in cell types that normally express $\mathrm{TH}$, but not $\mathrm{DBH}$. An interesting interpretation of this observation is that the DBH promoter fragment contains regulatory elements common to all catecholamine biosynthetic enzyme genes, but lacks silencer elements that normally restrict DBH expression to noradrenergic cell types (Mercer et al 1991). The TH promoter has also been extensively analyzed. Transfection experiments in PC12 cells have defined an enhancer necessary for cell type-specific expression (Gandelman et al 1990; Harrington et al 1987). Although an intact human TH gene is specifically expressed in transgenic mice (Kaneda et al 1991), promoter fragments able to direct correct heterologous transgene expression have not yet been identified for this gene. The transcription factors that interact with these cis-acting control elements have yet to be identified.

Promoters for several genes expressed not only in the SA progenitor, but also in most or all neurons, have also been studied. These include the type II sodium channel (Maue et al 1990), SCG10 (a growth-associated protein) (Mori et al 1990; Vandenbergh et al 1989; Wuenschell et al 1990), and synapsin I (Sauerwald et al 1990) (for further discussion, see the article by Mandel \& McKinnon in this volume). A surprising common feature of the regulation of these genes is that specificity is determined, at least in part, by selective derepression. The genes contain silencer elements that repress expression in non-neuronal cells and tissues; repression is specifically relieved in the nervous system. Recent data suggest that a common silencer mechanism may control the expression of both the type II sodium channel (Kraner et al 1992) and SCG10 (Mori et al 1992) genes. It remains to be determined when and how derepression occurs during neural crest development.

These data do not preclude a role for specifically expressed positiveacting factors in neurogenic determination. AP-2, a transcriptional activator protein, is specifically expressed in early migrating neural crest cells (Mitchell et al 1991). An insulin enhancer-binding homeodomain protein, Isl-1, is expressed in precursors to sensory and sympathetic neurons (as well as in motoneurons) (Thor et-al 1991; T. Jessell 1991, personal communication). A role for this molecule as a positive-acting transcription factor is supported by its sequence similarity with $\mathrm{mec}-3$, a homeodomain 
protein required for the development of mechanosensory neurons in $C$. elegans (Karlsson et al 1990; Way \& Chalfie 1988).

\section{THE SA LINEAGE IN MEDICINE AND DISEASE}

The study of the SA lineage has provided insights not only into vertebrate neurogenesis, but also into the diagnosis and treatment of human disease. For example, neuroblastomas and pheochromocytomas are tumors of the sympathoadrenal lineage that afflict young children (Israel 1991). Analysis of the phenotypes of these tumors using antibody and cloned cDNA markers (Cooper et al 1990a; Trojanowski et al 1991) has suggested that different subtypes of neuroblastomas may correspond to discrete stages of differentiation in the human SA lineage (Cooper et al 1990b; Molenaar et al 1990), which have been developmentally arrested by the process of oncogenic transformation. In particular, tumors can be defined that have either a more chromaffin-like phenotype or a more neuronal phenotype. These phenotypes correspond to the $\mathrm{SA}-1^{+} \mathrm{B} 22^{-}$"chromaffin precursor" stage and the SA-1-B2+ "committed neuroblast" stage identified in the rat SA lineage (Figure 2) (Anderson et al 1991; Carnahan \& Patterson 1991b). Interestingly, there is a correlation between tumor phenotype and prognosis. Patients whose tumors show a neuroblast phenotype have a much higher probability of spontaneous remission than those with tumors of a chromaffin phenotype (Israel 1991). The neuroblastic tumors may die because they become NGF-dependent and lack access to NGF. If so, a potential therapy for the more malignant chromaffin-like tumors might involve their in situ conversion to neuroblastic tumors, by using FGF and/or GCR antagonists. Other treatments might involve such factors as CDF/LIF and CNTF, which show an antiproliferative effect on SA progenitors (Ernsberger et al 1989b; Ip et al 1992).

Another area of medical research bearing on the SA lineage is the development of cell-replacement therapies for neurodegenerative diseases (Björklund 1991; Gage et al 1991). Adrenal chromaffin cell autografts have been used for the treatment of Parkinson's disease (Allen et al 1989), because they secrete dopamine, the missing neurotransmitter. However, such autografts have met with limited success. A more promising approach involves fetal donor tissue, which survives much better than adult tissue after grafting (Brundin et al 1986). The practical and ethical constraints on obtaining fetal donor tissue suggest that immortalized cell lines, from fetal SA progenitors as well as from other neuronal progenitors (Renfranz et al 1991; Snyder et al 1992), might prove usef ul in such cell-replacement therapies. Animal studies are now in progress to test this idea. The phenotypic plasticity and multipotentiality of SA lineage cells might make them 
useful in the treatment of other neurodegenerative diseases. For example, chromaffin cells and sympathetic neurons converted to a cholinergic phenotype by CDF/LIF have been tested for their ability to replace basal forebrain cholinergic neurons in an animal model of Alzheimer's disease (Mahanthappa et al 1990). In this way, the study of the SA lineage may have broader implications for both the understanding and treatment of human disease.

\section{PERSPECTIVES}

This review has focused on the biology of one developmentally restricted neural crest-derived progenitor cell. Although much less is known about the development of other neural crest derivatives, many of the general features of development in the SA lineage will probably apply to other crest lineages, as well. These features include the following: the generation of restricted progenitor cells; the determination of cell fate by environmental signals localized in different sites of migratory arrest; the ability of single environmental signals to promote one phenotype and repress another; the gain and loss of competence to respond to environmental signals during differentiation; and the ability of polypeptide growth factors to act sequentially as mitogens, differentiation factors, and survival factors. On the other hand, there are differences between the development of SA progenitors and that of other neural crest derivatives. Sympathoadrenal progenitors and sympathetic neuroblasts express differentiation genes (such as TH and neurofilament) while still proliferating; in other neuronal lineages, these genes are expressed subsequent to mitotic arrest (Anderson \& Axcl 1986; Rohrer \& Thoenen 1987). And, it is not yet clear whether the phenotypic plasticity exhibited by SA derivatives is also characteristic of neurons in other crest lineages. These distinctions may reflect fundamental differences in developmental mechanisms, or they may be superficial. Further work on other neural crest sublineages will be necessary to resolve these issues.

The SA lineagc has provided a well-characterized system for molecular studies of neural crest development; however, there have been recent spectacular advanccs in other aspects of neural crest molecular biology. Although beyond the scope of the present article, these deserve mention. The identification of the proto-oncogenc $\mathrm{p} 140^{\text {rrk }}$ as a tyrosine kinasecontaining NGF receptor has stimulated studies of signal transduction in PC12 cells (Kaplan et al 1991b; Kremer et al 1991; Sheng \& Greenberg 1990; Vetter et al 1991) and has revealed mechanistic analogies with invertebrate systems (for reviews, see Rubin 1991; Sternberg \& Horvitz 1991). The elucidation of the molecular bases of mouse mutations affecting 
melanocyte development has focused new attention on the role of polypeptide growth factors and their receptors in neural crest development (for reviews, see Bowen-Pope et al 1991; Marusich \& Weston 1991). And, a functional role for homeobox genes in the patterning of the cranial neural crest has been established by targeted mutagenesis of some Hox genes in mice (for review, see Hunt \& Krumlauf 1991). Over the next decade, these diverse approaches should converge with cellular studies to advance our understanding of many aspects of ncural crest development at the molccular level.

\section{SUMMARY}

Over the past five years, new insights have been gained into the biology of the SA lineage. These advances have been powered by the development of immunologic mcthods to isolate embryonic SA progenitors from fetal adrenal glands and sympathetic ganglia. Analysis of these embryonic progenitors has confirmed many of the ideas derived from earlier studies of postnatal cells, but has necessitated several revisions in our thinking, as well. First, embryonic SA progenitors appear to be distinct from mature SIF cells, a cell type initially postulated to be the central intermediate in the SA lineage. Second, FGF, not NGF, appears to be an important early influence on neuronal fate; NGF responsiveness appears relatively late in differentiation. Third, the development of both sympathetic neurons and adrenal chromaffin cells is not a one-step process, but rather involves a series of events, in which the cells change their responsiveness to growth factors and glucocorticoids. Fourth, emerging circumstantial evidence suggests that SA progenitors may have additional developmental potentials. Finally, new insights have been gained into the molecular mechanisms that underlie both the differentiation of SA progenitors and their determination from earlier multipotent neural crest cells. These advances have made the SA progenitor a well-defined system for studying the molecular control of cell fate in a vertebrate neurogenic precursor cell.

The analysis of the SA lineage at the cell biological level has raised several interesting molecular questions for future investigation. In the neuronal branch of the SA lineage, how is the acquisition of NGF-responsiveness and NGF-dependence controlled, and what is the relationship of these events to the expression of $\mathrm{p} 140^{\text {trk }}$ and $\mathrm{p} 75$ ? In the chromaffin branch of the pathway, which molecules control the timing of PNMT expression? In the uncommitted SA progenitor, what is the molecular basis of the antagonism between the competing neuronal and chromaffin pathways of differentiation, and how does commitment to neuronal differentiation occur? Can SA progenitors differentiate to enteric neurons in vitro, and 
which differentiation and survival factors control this phenotype, as well as the other classical neurotransmitter and neuropeptide phenotypes expressed by SA derivatives? What are the roles of MASHI and other regulatory genes in controlling early stages in neural crest cell determination, and how is the expression of these molecules in turn controlled? How much of the genetic regulatory network controlling neuronal differentiation in Drosophila has been conserved in vertebrates? These questions, and the further puzzles that their answers will inevitably create, promise fruitful territory for future investigations as the molecular biology of vertebrate neurogenesis comes of age.

\section{ACKNOWLEDGMENTS}

I thank Derek Stemple, Susan Birren, and Paul Patterson for their critical comments on this review, and Helen Walsh for her expert preparation of the manuscript. Work described in this review was supported by National Institutes of Health grant NS23476, a Pew Foundation Faculty Fellowship, and a Sloan Foundation Fellowship in Neuroscience.

\section{Literature Cited}

Abo, T., Balch, C. M. 1981. A differentiation antigen of human NK and $\mathrm{K}$ cells identified by a monoclonal antibody (HNK-1). J. Immunol. 127: 1024-29

Allen, G. S., Burns, R. S., Tulipan, N. B., Parker, R. A. 1989. Adrenal medullary transplantation to the caudate nucleus in Parkinson's Disease. Arch. Neurol. 46: 487-91

Aloe, L., Levi-Montalcini, R. 1979. Nerve growth factor-induced transformation of immature chromaffin cells in vivo into sympathetic neurons: Effects of antiserum to nerve growth factor. Proc. Natl. Acad. Sci. USA 76: 1246-50

Alonso, M. C., Cabrera, C. V. 1988. The achaete-scute complex of Drosophila melanngaster comprises four homologous genes. EMBO J. 7: 2585-91

Anderson, D. J. 1989. The neural crest cell lineage problem: Neuropoiesis? Neuron 3: $1-12$

Anderson, D. J. 1988. Cell fate and gene expression in the developing neural crest. In Neural Development and Regeneration, ed. A. Gorio, J. R. Perez-Polo, J. D. Vellis, B. Haber. NATO ASI Ser. H, 22: 188-98. Berlin/Heidelberg: Springer-Verlag

Anderson, D. J., Axel, R. 1986. A bipotential neuroendocrine precursor whose choice of cell $\mathrm{f}$ ate is determined by NGF and glucocorticoids. Cell 47: 1079-90
Anderson, D. J., Axel, R. 1985. Molecular probes for the development and plasticity of neural crest derivatives. Cell 42: 64962

Anderson, D. J., Carnahan, J., Michelsohn, A., Patterson, P. H. 1991. Antibody markers identify a common progenitor to sympathetic neurons and chromaffin cells in vivo, and reveal the timing of commitment to neuronal differentiation in the sympathoadrenal lineage. J. Neurosci. 11: 3507-19

Anderson, D. J., Michelsohn, A. 1989. Role of glucocorticoids in the chromaffinneuron developmental decision. Int. J. Dev. Neurosci. 12: 83-94

Baetge, G., Gershon, M. D. 1989. Transient catecholaminergic (TC) cells in the vagus nerves and bowel of fetal mice: relationship to the development of enteric neurons. Dev. Biol. 132: 189-211

Baetge, G., Pintar, J. E., Gershon, M. D. 1990. Transiently catecholaminergic (TC) cells in the bowel of the fetal rat: precursors of noncatecholaminergic enteric neurons. Dev. Biol. 141: 353-80

Barald, K. F. 1988. Antigen recognized by monoclonal antibodies to mesencephalic neural crest and to ciliary ganglion neurons is involved in the high affinity choline uptake mechanism in these cells. J. Neurosci. Res. 21: 119-34 
Barasch, J. M., Mackey, H., Tamir, II., Nunez, E. A., Gershon, M. D. 1987. Induction of a neural phenotype in a serotonergic endocrine cell derived from the neural crest. J. Neurosci. 7: 2874-83

Baroffio, A., Dupin, E., LeDouarin, N. M. 1988. Clone-forming ability and differentiation potential of migratory neural crest cells. Proc. Natl. Acad. Sci. USA 85: 5325-29

Batter, D. K., D’Mello, S. R., 'Turzai, L. M., Hughes, H. B. III, Gioio, A. E., Kaplan, B. B. 1988. The complete nucleotide sequence and structure of the gene encoding bovine phenylethanolamine $\mathrm{N}$ methyltransferase. J. Neurosci. Res. 19: 367-76

Beato, M. 1989. Gene regulation by steroid hormones. Cell 56: 335-44

Birren, S. J., Anderson, D. J. 1990. A v-mycimmortalized sympathoadrenal progenitor cell line in which neuronal differentiation is initiated by FGF but not NGF. Neuron 4: 189-201

Birren, S. J., Verdi, J., Anderson, D. J. 1992. Membrane depolarization induces p 140 trk and NGF-responsiveness, but not p75 ${ }^{\text {LNGFR }}$ in MAH cells. Science 257: 395-97

Björklund, A. 1991. Neural transplantation - an experimental tool with clinical possibilities. Trends Neurosci. 14: 319-22

Bohn, M. C., Goldstein, M., Black, I. B. 1982. Expression of phenylethanolamine $\mathrm{N}$-methyltransferase (PNMT) in rat sympathetic ganglia and extra-adrenal chromaffin tissue. Dev. Biol. 89: 299-308

Bohn, M. C., Goldstein, M., Black, I. 1981. Role of glucecorticoids in expression of the adrenergic phenotype in rat embryonic adrenal gland. Dev. Biol. 82: 1- 10

Bowen-Pope, D. F., van Koppen, $\Lambda$., Schatteman, G. 1991. Is PDGF really important? Testing the hypotheses. Trends Genet. 7: 413-17

Bronner-Fraser, M., Fraser, S. 1989. Developmental potential of avian trunk neural crest cells in situ. Neuron 3: 75566

Bronner-Fraser, M., Fraser, S. 1988. Cell lineage analysis shows multipotentiality of some a vian neural crest cells. Nature 335: 161-64

Brundin, P., Nilsson, O. G., Strecker, R. E., Lindvall, O., Åstedt, B., Björklund, A. 1986. Behavioural effects of human fetal dopamine neurons grafted in a rat model of Parkinson's disease. Exp. Brain Res. 65: 235-40

Campos-Ortega, J. A., Jan, Y. N. 1991. Genetic and molecular bases of neurogenesis in Drosophila melanogaster. Annu. Rev. Neurosci. 14: 399-420

Carnahan, J. F., Anderson, D. J., Patterson,
P. H. 1991. Evidence that enteric neurons may derive from the sympathoadrenal lineage. Dev. Biol. 148: 552-61

Carnahan, J. F., Patterson, P. H. 199la. Generation of monoclonal antibodies that bind preferentially to adrenal chromaffin cells and the cells of embryonic sympathetic ganglia. J. Neurosci. 11: 34933506

Carnahan, J. F., Patterson, P. H. 1991b. Isolation of the progenitor cells of the sympathoadrenal lineage from embryonic sympathetic ganglia with the SA monoclonal antibodies. J. Neurosci. 11:352030

Ceccatelli, S., Dagerlind, A., Schalling, M., Wikstrom, A.-C., Okret, S. 1989. The glucocorticoid receptor in the adrenal gland is located in the cytoplasm of adrenaline cells. Acta Phys. Scand. 137: 55960

Chun, L. L. Y., Patterson, P. H. 1977. Role of nerve growth factor in the development of rat sympathetic neurons in vitro..J. Cell Biol. 75: 694-704

Claude, P., Parada, I. M., Gordon, K. A., D'Amore, P. A., Wagner, J. A. 1988. Acidic fibroblast growth factor stimulates adrenal chromaffin cells to proliferate and to extend neurites, but is not a long-term survival factor. Neuron 1: 783-90

Cochard, P., Goldstein, M., Black, I. B. 1978. Ontogenic appearance and disappearance of tyrosine hydroxylase and catecholamines in the rat embryo. Proc. Natl. Acad. Sci. USA 75: 2986-90

Coffman, C., Harris, W., Kintner, C. 1990. Xotch, the Xenopus homolog of Drosophila notch. Science 249: 1438-41

Cooper, M. J., Hutchins, G. M., Cohen, P. S., Helman, L. J., Mennie, R. J., Israel, M. A. 1990a. Human neuroblastoma tumor cell lincs correspond to the arrested differcntiation of chromaffin adrenal medullary neuroblasts. Cell Growth Differ. 1: 149-59

Cooper, M. J., Hutchins, G. M., Israel, M. A. 1990b. Histogenesis of the human adrenal medulla: An evaluation of the onlogeny of chromaffin and nonchromaffin lineages. Am. J. Pathol. 137: 605-15

Coughlin, M. D., Collins, M. D. 1985. Nerve growth factor-independent development of embryonic mouse sympathetic neurons in dissociated cell culture. Dev. Biol. 110 : 392-401

Coulter, D. H., Gershon, M. D., Rothman, T. P. 1988. Neural and glial phenotypic expression by neural crest cells in culture: Effects of control and presumptive aganglionic bowel from $l s / l s$ mice. $J$. Neurobiol. 19: 507-31

Davies, A. M., Bandtlow, C., Heumann, R., 
Korsching, S., Rohrer, H., Thoenen, H. 1987. The site and timing of nerve growth factor (NGF) synthesis in developing skin in relation to its innervation by scnsory neurons and their expression of NGF receptors. Nature 326: 353-58

Diamond, M. I., Miner, J. N., Yoshinaga, S. K., Yamamoto, K. R. 1990. Transcription factor interactions: selectors of positive or negative regulation from a single DN $\Lambda$ element. Science 249: 1266-72

DiCicco-Bloom, E., Black, I. B. 1989. Depolarization and insulin-like growth factor-I (IGF-I) differentially regulate the mitotic cycle in cultured rat sympathetic neuroblasts. Brain Res. 491: 403-6

DiCicco-Bloom, E., Black, I. B. 1988. Insulin growth factors regulate the mitotic cycle in cultured rat sympathetic neuroblasts. Proc. Natl. Acad. Sci. USA 85: 4066-70

DiCicco-Bloom, E., Townes-Anderson, E., Black, I. B. 1990. Neuroblast mitosis in dissociated culture: regulation and relationship to differentiation. J. Cell Biol. 110: 2073-86

Doupe, A. J., Landis, S. C., Patterson, P. H. 1985a. Environmental influences in the development of neural crest derivatives: glucocorticoids, growth factors and chromaffin cell plasticity. J. Neurosci. 5: 211942

Doupe, A. J., Patterson, P. H., Landis, S. C. 1985b. Small intensely fluorescent (SIF) cclls in culturc: rolc of glucocorticoids and growth factors in their development and phenotypic interconversions with other neural crest derivatives. J. Neurosci. 5: 2143-60

Dupin, E., Baroffio, A., Dulac, C., CameronCurry, P., Le Douarin, N. M. 1990. Schwann-cell differentiation in clonal cultures of the neural crest, as evidenced by the anti-Schwann cell myelin protein monoclonal antibody. Proc. Natl. Acad. Sci. USA 87: 1119-23

Ehrlich, M. E., Evinger, M. J., Joh, T. H., Teitelman, G. 1989. Do glucocorticoids induce adrenergic differentiation in adrenal cells of neural crest origin? Dev. Brain Res. 50: 129-37

Eranko, O. 1975. SIF cells: structure and function of the small, intensely fluorescent sympathetic cells. Fogarty Int. Cent. Proc. No. 30, Dep. Health Educ. Welf. Publ. No. 76-942. Bethesda, MD: Natl. Inst. Health

Ernsberger, U., Edgar, D., Rohrer, H. 1989a. The survival of early chick sympathetic neurons in vitro is dependent on a suitable substrate but independent of NGF. Dev. Biol. 135: 250-62

Ernsberger, U., Sendtner, M., Rohrer, H. 1989b. Prolif eration and differentiation of embryonic chick sympathetic neurons: effects of ciliary neurotrophic factor. Neuron 2: 1275-84

Federoff, H. J., Grabczyk, E., Fishman, M. C. 1988. Dual regulation of GAP-43 gene expression by nerve growth factor and glucocorticoids. J. Biol. Chem. 263: 19290-95

Frank, E., Sanes, J. R. 1991. Lineage of neurons and glia in chick dorsal root ganglia: analysis in vivo with a recombinant retrovirus. Development 111: 895-908

Fraser, S. E., Bronner-Fraser, M. E. 1991. Migrating neural crest cells in the trunk of the avian embryo are multipotent. Development 112: 913-20

Gage, F. H., Kawa ja, M. D., Fisher, L. J. 1991. Genetically modified cells: applications for intracerebral grafting. Trends Neurosci. 14: 328-33

Gandelman, K. Y., Coker, G. T., Moffat, M., O’Malley, K. L. 1990. Species and regional differences in the expression of cell-type specific elements at the human and rat tyrosine hydroxylase gene loci. $J$. Neurochem. 55: 2149-52

Gard, A. L., Pteitfer, S. E. 1990. Two proliferative stages of the oligodendrocyte lincage (A2B5+O4 - and O4+ GalC-) under different mitogenic control. Neuron 5: 615-25

Ghysen, A., Dambly-Chaudiere, C. 1989. Genesis of the Drosophila peripheral nervous system. Trends Genet. 5: 251-55

Ghysen, A., Dambly-Chaudiere, C. 1988. From DNA to form: the achaete-scute complex. Genes Devel. 2: 495-501

Gonzalez, F., Romani, S., Cubas, P., Modolell, J., Campuzano, S. 1989. Molecular analysis of the asense gene, a member of the achaete-scute complex of Drosophila melanogaster, and its novel role in optic lobe development. EMBO J. 8: 3553-62

Greene, L. A., Tischler, A. S. 1976. Establishment of a noradrenergic clonal line of rat adrenal pheochromocytoma cells which respond to nerve growth factor. Proc. Natl. Acad. Sci. USA 73: 2424-28

Hall, A. K., Landis, S. C. 1991a. Early commitment of precursor cells from the rat superior cervical ganglion to neuronal or nonneuronal fates. Neuron 6: 741-52

Hall, A. K., Landis, S. C. 1991b. Principal neurons and small intensely fluorescent (SIF) cells in the rat superior cervical ganglion have distinct developmental histories. J. Neurosci. 11: 472-84

Harrington, C. A., Lewis, E. J., Krzemien, D., Chikaraishi, D. M. 1987. Identification and cell-type specificity of the tyrosine hydroxylase gene promoter. Nucl. Acids Res. 15: 2363-84

Hempstead, B. L., Martin-Zanca, D., Kaplan, D. R., Parada, L. F., Chao, M. V. 
1991. High-affinity NGF binding requires coexpression of the trk proto-oncogene and the low-affinity NGF receptor. Nature 350: $678-83$

Hillarp, N. A., Hökfelt, T. 1953. Evidence of adrenaline and noradrenaline in separate adrenal medullary cells. Acta Physiol. Scand. 30: 55-68

Holt, C. E., Bertsch, T. W., Ellis, H. M., Harris, W. A. 1988. Cellular determination in the Xenopus retina is independent of lineage and birth date. Neuron 1: $15-26$

Howard, M. J., Bronner-Fraser, M. 1985. The intluence of neural tube-derived factors on differentiation of neural crest cells in vitro. I. Histochemical study on the appearance of adrenergic cells. J. Neurosci. 5: 3302-9

Hunt, P., Krumlauf, R. 1991. Deciphering the Hox code: Clues to patterning branchial regions of the head. Cell 66: 107578

Ip, N. Y., Nye, S. H., Boulton, T. G., Davis, S., Taga, T., et al. 1992. CNTP and LIF act on neuronal cells via shared signalling pathways that involve the IL-6 signal transducing receptor component $\mathrm{gp}^{130}$. Cell 69: 1121-32

Israel, M. A. 1991. Molecular origins of pediatric embryonal tumors. Cancer Cells 3: 193-94

Jan, Y. N., Jan, L. Y. 1990. Genes required for specifying cell fates in Drosophila embryonic sensory nervous system. Trends Neurosci. 13: 493-98

Jiang, W., Uht, R., Bohn, M. C. 1989. Regulation of phenylethanolamine $\mathrm{N}$-methyltransferase (PNMT) mRNA in the rat adrenal medulla by corticosterone. Int. J. Dev. Neurosci. 7: 513-20

Johnson, D., Lanahan, A., Buck, C. R., Sehgal, A., Morgan, C., et al. 1986. Expression and structure of the human NGF receptor. Cell 47: 545-54

Johnson, J. E., Birren, S. J., Anderson, D. J. 1990. Two rat homologues of Drosophila achaete-scute specifically expressed in neuronal precursors. Nature 346: 858-61

Johnson, J. E., Birren, S. J., Saito, T., Anderson, D. J. 1992. The MASH genes encode transcriptional regulators that can activate expression of muscle creatine kinase, but do not induce myogenesis. Proc. Natl. Acad. Sci. USA 89: 3596-3600

Jonakait, G. M., Markey, K. A., Goldstein, M., Dreyfus, C. F., Black, I. B. 1985. Selective expression of high-affinity uptake of catecholamines by transiently catecholaminergic cells of the rat embryo: studies in vivo and in vitro. Dev. Biol. 108 : 6-17

Kalcheim, C., Neufeld, G. 1990. Expression of basic fibroblast growth factor in the nervous system of early avian embryos. Development 109: 203-15

Kaneda, N., Sasaoka, T., Kobayashi, K., Kiuchi, K., Nagatsu, I., et al. 1991. Tissuespecific and high-level expression of the human tyrosine hydroxylase gene in transgenic mice. Neuron 6: 583-94

Kaplan, D. R., Hempstead, B. L., MartinZanca, D., Chao, M. V., Parada, L. F. 1991a. The trk proto-oncogene product: a signal transducing receptor for nerve growth factor. Science 252: 554-58

Kaplan, D. R., Martin-Zanca, D., Parada, L. F. 1991b. Tyrosine phosphorylation and tyrosine kinase activity of the trk proto-oncogene product induced by NGF. Nature 350: 158-60

Kapur, R. P., Hoyle, G. W., Mercer, E. H., Brinster, R. L., Palmiter, R. D. 1991. Some neuronal cell populations express human dopamine $\beta$-hydrosylase-lac $\mathbf{Z}$ transgenes transiently during embryonic development. Neuron 7: 717-27

Karlsson, O., Thor, S., Norberg, T., Ohlsson, H., Edlund, T. 1990. Insulin gene enhancer binding protein Isl-I is a member of a novel class of proteins containing both a homeo- and a Cys-His domain. Nature 344: 879-82

Kessler, J. A., Cochard, P., Black, I. 1979. Nerve growth factor alters the fate of embryonic neuroblasts. Nature 280: 14142

Klein, R., Jing, S., Nanduri, V., O'Rourke, E., Barbacid, M. 1991. The trk protooncogene encodes a receptor for nerve growth factor. Cell 65: 189-97

Korsching, S., Thoenen, H. 1988. Developmental changes of nerve growth factor levels in sympathetic ganglia and their target organs. Dev. Biol. 126: 40-46

Kraner, S. D., Shong, J. A., Tsay, H.-J., Mandel, G. 1992. Silencing the type II sodium channel gene: a model for neuralspecific gene regulation. Ncuron 9: 37-44

Kremer, N., D'Arcangelo, G., Thomas, S., Demarco, M., Brugge, J. 1991. Signal transduction by nerve growth factor and fibroblast growth factor in PC12 cells requires a sequence of $\operatorname{src}$ and ras actions. J. Cell Biol. 115: 809-19

Kuo, M. D., Oda, Y., Huang, J. S., Huang S. S. 1990. Amino acid sequence and characterization of a heparin-binding neurite-promoting factor (P18) from bovine brain. J. Biol. Chem. 265: 18749-52

Landis, S. C., Keefe, D. 1983. Evidence for neurotransmitter plasticity in vivo: developmental changes in properties of cholinergic sympathetic neurons. Dev. Biol. 98: 349-72

Landis, S. C., Patterson, P. II. 1981. Neural 
crest cell lineages. Trends Neurosci. 4: 172 75

LeDouarin, N. M. 1982. The Neural Crest. Cambridge: Cambridge Univ. Press

LeDouarin, N. M. 1980. The ontogeny of the neural crest in avian embryo chimeras. Nature 286: 663-69

LeDouarin, N., Dulac, C., Dupin, E., Cameron-Curry, P. 1991. Glial cell lineages in the neural crest. Glia 4: 175-84

Leonard, D. G. B., Ziff, E. B., Greene, L. A. 1987. Identilication and characterization of $m$ RNAs regulated by nerve growth factor in PC12 cells. Mol. Cell. Biol. 7: 3156 57

Levi-Montalcini, R., Angeletti, P. U. 1963. Essential role of the nerve growth factor in the survival and maintenance of dissociated sensory and sympathetic embryonic nerve cells in vitro. Dev. Biol. 7: 65359

Levi-Montalcini, R., Booker, B. 1960. Destruction of the sympathetic ganglia in mammals by an antiserum to a nerve growth protein. Proc. Natl. Acad. Sci. USA 46: 384-91

Li, Y.-S., Milner, P. G., Chauhan, $\Lambda$. K., Watson, M. A., Hoffman, R. M., et al. 1990. Cloning and expression of a developmentally regulated protein that induces mitogenic and neurite outgrowth activity. Science 250: 1690-94

Lillien, L., Claude, P. 1985. Nerve growth factor is a mitogen for cultured chromaffin cells. Nature 317: 632-34

Lillien, L. E., Raff, M. C. 1990. Differentiation signals in the CNS: type-2 astrocyte development in vitro as a model system. Neuron 5: 111-19

Lo, L., Johnson, J. E., Wuenschell, C. W., Saito, T., Anderson, D. J. 1991. Mammalian achaete-scute homolog 1 is transiently expressed by spatially-restricted subsets of early neuroepithelial and neural crest cells. Genes Dev. 5: 1524-37

Machida, C. M., Rodland, K. D., Matrisian, L., Magun, B. E., Ciment, G. 1989. NGF induction of the gene encoding the protease transin accompanies neuronal differentiation in PCI2 cells. Neuron 2: 1587-96

Mackey, H. M., Payette, R. F., Gershon, M. D. 1988. Tissue effect on the expression of serotonin, tyrosine hydroxylase and GABA in cultures of neurogenic cells from the neuraxis and branchial arches. Development 104: 205-17

Mahanthappa, N. K., Gage, F. H., Patterson, P. H. 1990. Adrenal chromaffin cells as multipotential neurons for autografts. In Progress in Brain Research, ed. S. B. Dunnett, S.-J. Richards, 82: 33-39

Marusich, M. F., Weston, J. A. 1992. Identi- fication of early neurogenic cclls in the neural crest lincage. Dev. Biol. 149: 295306

Marusich, M. F., Weston, J. A. 1991. Development of the neural crest. Curr. Opin. Genet. Devel. 1: 221-29

Maue, R. A., Kraner, S. D., Goodman, R. H., Mandel, G. 1990. Neuron-specilic expression of the rat brain type II sodium channel gene is directed by upstream regulatory elements. Neuron 4: 223-31

Maxwell, G. D., Forbes, M. E. 1990a. Exogenous basement membrane-like matrix stimulates adrenergic development in avian neural crest cultures. Development 101: 767-76

Maxwell, G. D., Forbes, M. E. 1990b. The phenotypic response of cultured quail trunk neural crest cells to a reconstituted basement membrane-like matrix is specific. Dev. Biol. 141: 233-37

Mercer, E. H., Hoyle, G. W., Kapur, R. P., Brinster, R. L., Palmiter, R. D. 1991. The dopamine $\beta$-hydroxylase gene promoter directs expression of E. coli lac $Z$ to sympathetic and other neurons in transgenic mice. Neuron 7: 703-16

Michelsohn, A., Anderson, D. J. 1992. Changes in competence determine the timing of two scquential glucocorticoid effects on sympathoadrenal progenitors. Neuron 8: 589-604

Michelson, A. M., Abmayr, S. M., Bate, M., Arias, A. M., Maniatis, T. 1990. Expression of a MyoD family member prefigures muscle pattern in Drosophila embryos. Genes Dev. 4: 2086-97

Mitchell, P. J., Timmons, P. M., Hébert, J. M., Rigby, P. W. J., Tjian, R. 1991. Transcription factor AP-2 is expressed in neural crest cell lineages during mouse embryogenesis. Genes Dev. 5: 105-19

Molenaar, W. M., Lee, V. M.-Y., Trojanowski, J. Q. 1990. Early fetal acquisition of the chromaffin and neuronal immunophenotype by human adrenal medullary cells. An immunohistological study using monoclonal antibodies to chromogranini A, synaptophysin, tyrosine hydroxylase and neuronal cytoskeletal proteins. Exp. Neurol. 108: 1-9

Mori, N., Schoenherr, C., Vandenbergh, D. J., Anderson, D. J. 1992. A common silencer element in the SCG10 and type II $\mathrm{Na}^{+}$channel genes binds a factor present in nonneuronal cells but not in neuronal cells. Neuron 9: 45-54

Mori, N., Stein, R., Sigmund, O., Anderson, D. J. 1990. A cell type-preferred silencer element that controls the neural-specific expression of the SCG10 gene. Neuron 4: 583-94

Murre, C., McCaw, P. S., Baltimore, D. 
1989a. A new DNA binding and dimerization motif in immunoglobin enhancer binding, daughterless, $M$ yoD and $m y c$ proteins. Cell 56: 777-83

Murre, C., McCaw, P. S., Vaessin, H., Caudy, M., Jan, L. Y., et al. 1989b. Interactions between heterologous helix-loophelix proteins generate complexes that bind specifically to a common DNA sequence. Cell 58: 537-44

Nawa, H., Patterson, P. H. 1990. Separation and partial characterization of neuropeptide-inducing factors in heart cell conditioned medium. Neuron 4: 269-77

Ogawa, M., Ishikawa, I., Irimajiri, A. 1984. Adrenal chromaffin cells form functional cholinergic synapses in culture. Nature 307: 66-68

Olson, L. 1970. Fluorescence histochemical evidence for axonal growth and secretion from transplanted adrenal medullary tissue. Histochemie 22: 1-7

Patterson, P. H. 1990. Control of cell fate in a vertebrate neurogenic lineage. Cell 62: 1035-38

Patterson, P. H. 1978. Environmental determination of autonomic neurotransmitter functions. Annu. Rev. Neurosci. 1: 1-17

Patterson, P. H., Chun, L. L. Y. 1977. The induction of acetylcholine synthesis in primary cultures of dissociated rat sympathetic neurons. I. Effects of conditioned medium. Dev. Biol. 56: 263-80

Pincus, D. W., DiCicco-Bloom, E. M., Black, I. B. 1990. Vasoactive intestinal peptide regulates mitosis, differentiation and survival of cultured sympathetic neuroblasts. Nature 343: 564-67

Pohorecky, L. A., Wurtman, R. J. 1971. Adrenocortical control of epinephrine synthesis. Pharmacol. Rev. 23: 1-35

Radeke, M. J., Misko, T. P., Hsu, C., Herzenberg, L. A., Shooter, E. M. 1987. Gene transfer and molecular cloning of the rat nerve growth factor receptor. Nature 325 : 593-97

Raff, M. C. 1989. Glial cell diversification in the rat optic nerve. Science 243: 1450-55

Rao, M. S., Landis, S. C. 1990. Characterization of a target-derived neuronal cholinergic differentiation factor. Neuron S: 899-910

Renfranz, P. J., Cunningham, M. G., McKay, R. D. G. 1991. Region-specific differentiation of the hippocampal stem cell line HiB5 upon implantation into the developing mammalian brain. Cell 66: 713-29

Rodriguez-Tébar, A., Rohrer, H. 1991. Retinoic acid induces NGF-dependent survival response and high-affinity NGF receptors in immature chick sympathetic neurons. Development 112: 813-20
Rohrer, H. 1990. The role of growth factors in the control of neurogenesis. Eur. J. Neurosci. 2: 1005-15

Rohrer, H., Hofer, M., Hellweg, R., Korsching, S., Stehle, A. D., et al. 1988. Antibodies against mouse nerve growth factor interfere in vivo with the development of avian sensory and sympathetic neuroncs. Development 103: 545-52

Rohrer, H., Thoenen, H. 1987. Relationship between differentiation and terminal mitosis: chick sensory and ciliary neurons differentiate af ter terminal mitosis of precursor cells, whereas sympathetic neurons continue to divide after differentiation. $J$. Neurosci. 7: $3739-48$

Romani, S., Campuzano, S., Macagno, E. R., Modolell, J. 1989. Expression of achaete and scute genes in Drosophila imaginal discs and their function in sensory organ development. Genes Dev. 3: 997-1007

Roos, T. H. 1967. Steroid synthesis in embryonic and fetal rat adrenal tissue. Endocrinology 81: 716-28

Ross, M. E., Evinger, M. J., Hyman, S. E., Carroll, J. M., Mucke, L., et al. 1990. Identification of a functional glucocorticoid response element in the phenylethanolamine $\mathrm{N}$-methyltransferase promoter using fusion genes introduced into chromaffin cells in primary culture. $J$. Neurosci. 10: 520-30

Rubin, G. M. 1991. Signal transduction and the fate of the R7 photoreceptor in Drosophila. Trends Genet. 7: 372-77

Rydel, R. E., Greene, L. A. 1987. Acidic and basic fibroblast growth factors promote stable neurite outgrowth and neuronal differentiation in cultures of $\mathrm{PC} 12$ cells. $J$. Neurosci. 7: 3639-53

Saadat, S., Sendtner, M., Rohrer, H. 1989. Ciliary neurotrophic factor induces cholinergic differentiation of rat sympathetic neurons in culture. J. Cell Biol. 108: 1807-16

Sah, D. W. Y., Matsumoto, S. G. 1987. Evidence for serotonin synthesis, uptake and release in dissociated rat sympathetic neurons in culture. J. Neurosci. 7: 391-99

Sanes, J. R., Rubenstein, J. L. R., Nicolas, J. F. 1986. Use of a recombinant retrovirus to study post-implantation cell lineage in mouse embryos. EMBO J. 5: 3133-42

Satoh, T., Nakamura, S., Taga, T., Matsuda, T., Hirano, T., et al. 1988. Induction of neuronal differentiation in $\mathrm{PC} 12$ cells by B-cell stimulatory factor $2 /$ Interleukin 6 . Mol. Cell. Biol. 8: 3546-49

Sauerwald, A., Hoesche, C., Oschwald, R., Kilimann, M. W. 1990. The 5'-flanking region of the synapsin-I gene-a $\mathrm{G}+\mathrm{C}$ rich, TATA-less and CAAT-less, phylo- 
genetically conserved sequence with cell type-specific promoter function. J. Biol. Chem. 265: 14932-37

Schotzinger, R. J., Landis, S. C. 1990. Acquisition of cholinergic and peptidergic properties by sympathetic innervation of rat sweat glands requires interaction with normal target. Neuron 5: 91-100

Schotzinger, R., Landis, S. C. 1988. Cholinergic phenotype developed by noradrencrgic sympathetic neurons after innervation of a novel cholinergic target in vivo. Nature 335: 637-39

Schiile, R., Evans, R. M. 1991 . Cross-coupling of signal transduction pathways: Ainc finger meets leucine zipper. Trends Genet. 7: $377-81$

Schüle, R., Rangarajan, P., Kliewer, S., Ransone, L. J., Bolado, J., et al. 1990. Functional antagonism between oncoprotein cJun and the glucocorticoid receptor. Cell 62: 1217-26

Seidl, K., Unsicker, K. 1989a. Survival and neuritic growth of sympathoadrenal (chromaffin) precursor cells in vitro. Int. J. Dev. Neurnsci. 7: 465-73

Seidl, K., Unsicker, K. 1989b. The determination of the adrenal medullary cell fate during embryogenesis. Dev. Biol. 136: $481-90$

Sheng, M., Greenberg, M. E. 1990. The regulation and function of c-fos and other immediate early genes in the nervous system. Neuron 4: 477-85

Sieber-Blum, M. 1990. Mechanisms of neural crest diversification. In Comments Developmental Neurobiology, 1: 225-49. London: Gordon \& Breach

Sieber-Blum, M., Cohen, A. 1980. Clonal analysis of quail neuralcrest cells: they are pluripotent and differentiate in vitro in the absence of non-neural crest cells. Dev. Biol. 80: 96-106

Simons, S. S. J., Mercier, L., Miller, N. R., Miller, P. A., Oshima, H., et al. 1989. Differential modulation of gene induction of glucocorticoids and antiglucocorticoids in rat hepatoma tissue culture cells. Cancer Res. 49: 2244s-52s

Snyder, E. Y., Deitcher, D. L., Walsh, C., Arnold-Aldea, S., Hartweig, E. A., Cepko, C. L. 1992. Multipotent neural cell lines can engraft and participate in development of mouse cerebellum. Cell 68: 33-51

Soinila, S., Ahonen, M., Lahtinen, T., Häppölä, O. 1989. Developmental changes in 5-hydroxytryptamine immunoreactivity of sympathetic cells. Int. J. Dev. Neurosci. 7: $553-63$

Stein, R., Orit, S., Anderson, D. J. 1988. The induction of a neural-specific gene, SCG10, by nerve growth factor in $\mathrm{PCl} 2$ cells is transcriptional, protein synthesis dependent, and glucocorticoid inhibitable. Dev. Biol. 127: 316-25

Stemple, D. L., Mahanthappa, N. K., Anderson, D. J. 1988. Basic FGF induces neuronal differentiation, cell division, and NGF dependence in chromaffin cells: a sequence of events in sympathetic development. Neuron 1: 517-25

Stern, C. D., Artinger, K. B., BronnerFrascr, M. 1991. Tissue interactions affecting the migration and differentiation of neural crest cells in the chick embryo. Development 113: 207-16

Sternberg, P. W., Horvitz, H. R. 1991. Signal transduction during $C$. elegans vulval induction. Trends Genet. 7: 366-71

Suda, T., Suda, J., Ogawa, M. 1984. Disparate differentiation in mouse hemopoietic colonies derived from paired progenitors. Proc. Natl. Acad. Sci. USA 81: 2520-24

Szabo, A., Dalmau, J., Manley, G., Rosenfeld, M., Wong, E., et al. 1991. HuD, a paraneoplastic encephalomyelitis antigen, contains RNA-binding domains and is homologous to Elav and Sex-lethal. Cell 67: $325-33$

Teitelman, G., Joh, T. H., Park, D., Brodsky, M., New, M., Reis, D. J. 1982. Expression of the adrenergic phenotype in cultured fetal adrenal medullary cells: role of intrinsic and extrinsic factors. Dev. Biol. 80: 450-59

Teitelman, G., Joh, T. H., Reis, D. J. 1978. Transient expression of a noradrenergic phenotype in cells of the rat embryonic gut. Brain Res. 158: 229-34

Thor, S., Ericson, J., Brännström, T., Edlund, T. 1991. The homeodomain LIM protein Is $1-1$ is expressed in subsets of neurons and endocrine cells in the adult rat. Neuron 7: 1-20

Togari, A., Dickens, G., Kuzuya, H., Guroff, G. 1985. The effect of fibroblast growth factor on PC12 cells. J. Neurosci. 5: 307 16

Trojanowski, J. Q., Molcnaar, W. M., Baker, D. L., Pleasure, D., Lee, V. M.-Y. 1991. Neural and neuroendocrine phenotype of neuroblastomas, ganglioneuroblastomas, ganglioneuromas and mature versus embryonic human adrenal medullary cells. In Advances in Neuroblastoma Research, 3: 335-41. New York: WileyLiss

Turner, D. L., Cepko, C. 1987. A common progenitor for neurons and glia persists in rat retina late in development. Nature 328: 131-36

Unsicker, K., Drisch, B., Otten, J., Thoenen, H. 1978. Nerve growth factor-induced fiber outgrowth from isolated rat adrenal 
chromaffin cells: impairment by glucocorticoids. Proc. Natl. Acad. Sci. USA 75: 3498-3502

Unsicker, K., Seidl, K., Hofmann, H. D. 1989. The neuro-endocrine ambiguity of sympathoadrenal cells. Int. J. Dev. Neurosci. 7: 413-17

Vandenbergh, D. J., Mori, N., Anderson, D. J. 1991. Co-expression of multiple neurotransmitter enzyme genes in normal and immortalized sympathoadrenal progenitor cells. Dev. Biol. 148: 10-22

Vandenbergh, D. J., Wuenschell, C. W., Mori, N., Anderson, D. J. 1989. Chromatin structure as a molecular marker of cell lincagc and developmental potential in neural crest-derived chromaffin cells. Neuron 3: 507-18

Vetter, M. L., Martin-Zanca, D., Parada, L. F., Bishop, J. M., Kaplan, D. R. 1991. Nerve growth factor rapidly stimulates tyrosine phosphorylation of phospholipase $C-\gamma 1$ by a kinase activity associated with the product of the trk protooncogene. Proc. Natl. Acad. Sci. USA 88: 5650-54

Villares, R., Cabrera, C. V. 1987. The achaetescute gene complex of $\mathrm{D}$. melanogaster: conserved domains in a subset of genes required for neurogenesis and their homology to myc. Cell 50: 415-24

Vogel, K. S., Davies, A. M. 1991. The duration of neurotrophicfactor independence in early sensory neurons is matched to the time course of target field innervation. Neuron 7: 819-30

Vogel, K. S., Weston, J. A. 1988. A subpopulation of cultured avian neural crest cells has transient neurogenic potential. Neuron 1: 569-77

Vogel, K. S., Weston, J. A. 1990. The sympathoadrenal lineage in avian embryos. I. Adrenal chromaffin cells lose neuronal traits during embryogenesis. Dev. Biol. 139: $1-12$

Way, J. C., Chalfic, M. 1988. mec-3, a homeobox-containing gene that specifies differentiation of the touch receptor neurons in C. elegans. Cell 54: 5-16
Weinmaster, G., Roberts, V. J., Lemke, G. 1991. A homolog of Drosophila Notch expressed during mammalian development. Development 113: 199-205

Weintraub, H., Davis, R., Tapscott, S., Thayer, M., Krause, M., et al. 1991. The myoD gene family: nodal point during specification of the muscle cell lineage. Science 251: 761-66

Weskamp, G., Reichardt, L. F. 1991. Evidence that biological activity of NGF is mediated through a novel subclass of high affinity receptors. Neuron 6: 649-63

Wetts, R., Fraser, S. E. 1988. Multipotent precursors can give rise to all ma jor typcs of the frog retina. Science 239: 1142-45

Wolinsky, E. J., Landis, S. C., Patterson, P. H. 1985. Expression of noradrenergic and cholinergic traits by sympathetic neurons cultured without serum. J. Neurosci. 5: 1497-1508

Wolswijk, G., Noble, M. 1989. Identification of an adult-specific glial progenitor cell. Development 105: 387-400

Wuenschell, C. W., Mori, N., Anderson, D. J. 1990. Analysis of SCGI0 gene expression in transgenic mice reveals that neural specificity is achieved through selective derepression. Neuron 4: 595602

Wurtman, R. J., Axelrod, J. 1966. Control of enzymatic synthesis of adrenaline in the adrenal medulla by adrenal cortical steroids. J. Biol. Chem. 241: 2301-5

Yamamori, Y., Fukada, K., Aebersold, R., Korsching, S., Fann, M.-J., Patterson, P. H. 1989. The cholinergic neuronal differentiation factor from heart cells is identical to leukemia inhibitory factor. Science 246: 1412-16

Yang-Yen, H. F., Chambard, J.-C., Sun, Y.-L., Smeal, T., Schmidt, T. J., et al. 1990. Transcriptional interference between C-Jun and the glucocorticoid receptor: mutual inhibition of DN $\Lambda$ binding due to direct protein-protein interaction. Cell 62: 1205-15 